\title{
The influence of low temperature on the evolution of concrete strength
}

\section{A influência das baixas temperaturas na evolução das resistências do concreto}
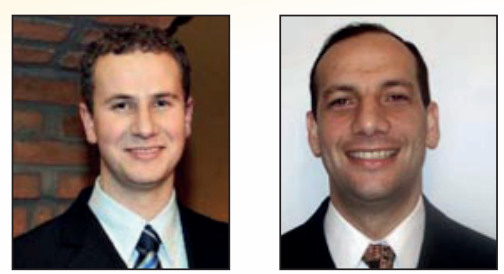

\author{
V. CECCONELLO \\ vcecconello@gmail.com \\ B. TUTIKIAN \\ bftutikian@unisinos.br
}

\begin{abstract}
The mechanical strength of concrete can be affected by many conditions, among them the proportion of the mixture and the influence of external agents, such as external temperatures. Thus, the objective of the paper is to analyze the influence of low temperature on the evolution of concrete strength, from the molding of tests specimens cured at various temperatures. The specimens were submitted in the first 7 days, as curing temperatures ranging from $0^{\circ} \mathrm{C}$ to $25^{\circ} \mathrm{C}$, simulating the lowest possible value for the start of the cement hydrations reactions to the considered ideal for development resistances. The results of the experimental program demonstrated at lower cure temperatures the strength of the mixture develops more slowly, as might be expected, but also found after 14 days, the strength of the mixtures was reversed, i.e., concretes cured at higher temperatures lower values. Thus, it was concluded the concrete in cold weather can be beneficial to its mechanical performance to over time, at the expense constructive steps in normal temperature.
\end{abstract}

Keywords: external agents, low temperatures cure, evolution of resistance, hydration heat of Portland cement paste.

\section{Resumo}

As resistências mecânicas do concreto podem ser afetadas por inúmeros condicionantes, como a proporção entre os seus constituintes e a influência de agentes externos, como a temperatura ambiente. Com isso, o objetivo deste artigo é analisar a influência das baixas temperaturas na evolução das resistências do concreto a base de cimento Portland, a partir da moldagem de corpos-de-prova curados em temperaturas variadas. Os corpos-de-prova foram submetidos, nos primeiros 7 dias, a temperaturas de cura que variaram de $0^{\circ} \mathrm{C}$ até $25^{\circ} \mathrm{C}$, simulando as temperaturas mais baixas possíveis para o início das reações de hidratação do cimento até os valores considerados ideais para o desenvolvimento das resistências. Os resultados do programa experimental demonstraram que em temperaturas de cura inferiores a resistência à compressão da mistura se desenvolve mais lentamente, como era de se esperar, porém também verificou-se que a partir dos 14 dias, as resistências das misturas se inverteram, ou seja, os concretos curados a temperaturas superiores apresentaram valores menores. Com isso, concluiu-se que a concretagem em dias frios pode ser vantajosa para o seu desempenho mecânico ao longo do tempo, apesar de prejudicar etapas construtivas em situações normais de temperatura.

Palavras-chave: agentes externos, curas a baixas temperaturas, evolução de resistência, calor de hidratação da pasta de cimento Portland.

a Programa de Pós Graduação em Engenharia Civil, PPGEC, Unisinos, vcecconello@gmail.com - Av. Unisinos, 950, centro 6 - Exatas, São Leopoldo / RS, Brasil;

b Programa de Pós Graduação em Engenharia Civil, PPGEC, Unisinos, bftutikian@unisinos.br - Av. Unisinos, 950, centro 6 - Exatas, São Leopoldo / RS, Brasil. 


\section{Introduction}

The reinforced concrete has been established over the years as one of the most used building systems. According to Helene and Levy (2003) [1], the concrete will have a more promising future in the coming decades, once its architectural versatility, combined with increased durability, will enable the implementation and the development of any project.

For the concrete to achieve the forecasted resistances for the good functioning, it is necessary that hydration reactions are completed between cement and water. Therefore, the external temperature behaves as a catalyst of these reactions, the hotter it is, and the faster these reactions occur.

According to Shoukry et al. (2010) [2], the temperature, along with the relative humidity of the air plays a big role in the reactions of the hydration of the cement paste by affecting the properties of fresh and hardened concrete.

However, Brazil is comprised of a large territory, encompassing many kinds of weather conditions, including low temperatures in certain periods of the year. In the South region, for example, the weather can be compared to that of other Latin American countries and the world, where the incidence of low temperatures over long periods of the year is characterized by a temperate climate. Yet, the Brazilian norm of project of concrete structures, the ABNT NBR 6118:2007 [3] does not distinguish between the regions of the country or external temperatures. Structural designs, and consequently, the execution have been achieved without caution, in respect to temperature control in the early days of curing, which may lead to irreversible problems in these structures.

According to Mehta and Monteiro (2008) [4]:

"In this respect, the concrete equates to a child: to become a healthy adult, the newborn needs special attention in the first times of growth. However, in both instances, there is no clear definition of how long this early age period lasts."

The Portland cement, by reacting with water, forms a paste with more or less fluidity, depending on the percentage of added water. In the course of time, this mixture hardens by irreversible reaction of water with cement, acquiring mechanical strength able to turn it in an excellent material for structural performance, under the most diverse exposure environments (Isaia, 2005 [5]).

According to Anka et al. (2009) [6], the entire process of hydration of the cement in concrete is very complex, and can be influenced by many factors. Among the properties most impact the hydration process is the initial temperature of the concrete and also the temperature of air.

The tricalcium aluminate $\left(\mathrm{C}_{3} \mathrm{~A}\right)$, a component of the cement hydrates at a rate much quicker than the silicates. Neville (1997) [7] quotes the reactions of pure $\mathrm{C}_{3} \mathrm{~A}$ with water occur in a violent manner and results in an immediate hardening of the cement paste, also known as instant concrete setting time. In order to prevent this, gypsum $\left(\mathrm{CaSO} .2 \mathrm{H}_{2} \mathrm{O}\right)$ is added to the clinker manufacturing process of Portland cement. According to Kirchheim et al. (2010) [8], an example of the action of the $C_{3} A$ can be seen in the execution of Iberê Camargo museum in Porto Alegre, where it was used white Portland cement with $\mathrm{C}_{3} \mathrm{~A}$ contents above $9 \%$.

The calcium silicates $\left(\mathrm{C}_{3} \mathrm{~S}\right.$ e $\left.\beta \mathrm{C}_{2} \mathrm{~S}\right)$ are responsible for about $75 \%$ of the constitution of ordinary Portland cement, exerting a dominating role in determining the characteristics of hardness, also known as the rate of development of resistance. The hydration of $\mathrm{C}_{3} \mathrm{~S}$ and $\beta_{2} S$ in the Portland cement produces $\beta_{2} S$ in a family of the hydrated calcium silicates, which have similar structures that vary widely in the relation between calcium and silica in addition to the chemically combined water content (Mehta and Monteiro, 2008) [4]. However, the tetracalcium ferroaluminate $\left(C_{4} A F\right)$ results in hydration products structurally similar to the products of $C_{3} A$, though the reactivity of $\mathrm{C}_{4} \mathrm{AF}$ is slower (Neville, 1997) [7].

In parallel to the reactions, the heat of hydration of the Portland cement is generated which can be observed as a thermal energy resulting from the contact with water. This development of heat occurs quickly from the mixture of Portland cement clinker milled with water. The hydration of cement is characterized as an exothermic reaction, that is, a reaction that generates heat, thus the hydration process is directly related to the amount of heat generated.

Hence, what is expected of the Portland cement is a good correlation between the rate of the cement hydration and the heat of hydration. Cements with high hydration heat, hydrate faster compared to cements that generate less heat of hydration (Taylor, 1967) [9]. Kirchheim et al. (2010) [8] add that in certain works use large amounts of concrete, its thermal conductivity can be low and with a high heat release due to the hydration reaction, which can generate cracks through thermal retraction.

According to Mehta and Monteiro (2008) [4] the heat of hydration can sometimes be unfavorable, for example, in the mass-concrete structures. And sometimes be favorable, for example, in concrete work in the winter or in regions of low temperatures when the environment temperature may be too low to supply the energy required for the activation of the initial reactions of hydration. According to Zhang et al. (2008) [10], there is not a single value of activation energy for all concrete and their different formulations.

According to Pinto Barbosa et al. (2006) [11], the whole process of hydration of the cement can be compared starting from an evolutionary rate that depends on the concentration and temperature of all reagents of the solution. The hydration is accelerated at high temperatures and reduced at lower temperatures. Kim et al. (2002) [12] emphasize that concrete subjected to high temperatures at early ages reach higher early resistance, but reduce the growth rate of resistance over time. Husem and Gözütok (2004) [13] add that cures at high temperatures reduce the strength of concrete including being applied to conventional molded parts in conventional concrete and of high performance, which can cause problems in the future.

When the concrete is in a period of solidification or in the beginning of hardening, and has interference by low temperatures, these actions have a tendency to be decelerated or even reversed owing to the reduction in the rate of hydration of the active components of the cement (Cánovas, 1988) [14]. As for the heating, the mechanical properties of concrete decrease remarkably, resulting in a decrease in the quality of the concrete structure (Kelestemur and Demirel, 2010) [15].

According to Shoukry et al. (2010) [2], one must consider in structural design the variability of the evolution of concrete properties due to temperature, as this may affect their structural behavior. The authors demonstrated for a thermal variation of $80^{\circ} \mathrm{C}(-25$ to $55{ }^{\circ} \mathrm{C}$ ) at 28 days of curing, there is a reduction of $38 \%$ and $26 \%$ of the resistance to compression and tension, respectively. However, the work was conducted in extreme temperature conditions of cur- 


\section{Table 1 - Chemical composition of cement}

\begin{tabular}{|c|c|c|}
\hline Mechanical Properties & Testing of cement & Limit Standard \\
\hline Finesse \#200 (75mm) & 2,49 & 12 \\
\hline Finesse \#325 (45mm) & 10,81 & - \\
\hline Finesse Blaine $\left(\mathrm{g} / \mathrm{cm}^{2}\right)$ & 3472 & 2600 \\
\hline Initiation take time (min) & 190 & 60 \\
\hline End take time (min) & 310 & 600 \\
\hline Compressive strength, 3 days (MPa) & 26,1 & 10 \\
\hline Compressive strength, 7 days (MPa) & 31,3 & 20 \\
\hline Compressive strength, 28days (MPa) & 40,4 & 32 \\
\hline Chemical Properties & Testing of cement & Limit Standard \\
\hline Insoluble residue (\%) & 1,24 & 2,5 \\
\hline Loss on ignition (\%) & 4,10 & 6,5 \\
\hline $\mathrm{MgO}(\%)$ & 1,81 & 6,5 \\
\hline $\mathrm{SO}_{3}(\%)$ & 2,00 & 4,0 \\
\hline $\mathrm{Na}_{2} \mathrm{O}(\%)$ & 0,11 & - \\
\hline $\mathrm{K}_{2} \mathrm{O}(\%)$ & 0,71 & - \\
\hline
\end{tabular}

ing, a condition rarely observed. There is no agreement on the behavior of concrete under low temperature, but positive, even for the lack of results with these characteristics.
In this research, in the middle of this, it was intendded to analyze the influence of external low temperature of the concrete at early ages in order to determine their mechanical properties under this condition.

\section{Table 2 - Particle size analysis of fine and coarse aggregate}

\begin{tabular}{|c|c|c|c|c|}
\hline \multirow[b]{2}{*}{ Opening of sieves (mm) } & \multicolumn{2}{|c|}{ Fine aggregate } & \multicolumn{2}{|c|}{ Coarse aggregate } \\
\hline & Retained (\%) & $\begin{array}{l}\text { Accumulated } \\
\text { retained }(\%)\end{array}$ & Retained (\%) & $\begin{array}{l}\text { Accumulated } \\
\text { retained }(\%)\end{array}$ \\
\hline \# 19 & 0 & 0 & 0 & 0 \\
\hline$\# 12,5$ & 0 & 0 & 31,6 & 31,6 \\
\hline \# 9,5 & 0 & 0 & 45,2 & 76,8 \\
\hline$\# 6,3$ & 0 & 0 & 22,6 & 99,4 \\
\hline$\# 4,8$ & 0 & 0 & 0,6 & 100 \\
\hline$\# 2,4$ & 0,3 & 0,3 & 0 & 100 \\
\hline$\# 1,2$ & 1,1 & 1,4 & 0 & 100 \\
\hline$\# 0,6$ & 10,4 & 11,8 & 0 & 100 \\
\hline$\# 0,3$ & 45,5 & 57,3 & 0 & 100 \\
\hline \# 0,15 & 33,2 & 90,5 & 0 & 100 \\
\hline background $(<0,075)$ & 9,5 & 100 & 0 & 100 \\
\hline Fineness modulus & \multicolumn{2}{|c|}{1,61} & \multicolumn{2}{|c|}{6,77} \\
\hline Maximum size & \multicolumn{2}{|c|}{$1,2 \mathrm{~mm}$} & \multicolumn{2}{|c|}{$19 \mathrm{~mm}$} \\
\hline Specific gravity & \multicolumn{2}{|c|}{$2618 \mathrm{~kg} / \mathrm{m}^{3}$} & \multicolumn{2}{|c|}{$2590 \mathrm{~kg} / \mathrm{m}^{3}$} \\
\hline Unit mass released in the state & \multicolumn{2}{|c|}{$1419 \mathrm{~kg} / \mathrm{m}^{3}$} & \multicolumn{2}{|c|}{1197 kg/m³ } \\
\hline
\end{tabular}




\section{Objective}

The overall goal of this study was to compare the resistances to compression at 1, 7, 28 and 91 days and 28 days to traction for the cured concrete at temperatures ranging from zero to $25^{\circ} \mathrm{C}$, with intervals of $5{ }^{\circ} \mathrm{C}$, thus analyzing the influence external temperature on the development of the mechanical properties of concrete.

\section{Experimental Programme}

For the accomplishment of the trial program it was aimed the reproduction of the effect of the external temperature on the concrete, by controlling the curing temperature of the specimens. Thus, the samples were conditioned to various cures in the first seven days, for testing the resistance to compression and traction.

It was given a trace to obtain the resistance to compression common to project, around $25 \mathrm{MPa}$ at 28 days. For this purpose, it was defined the trace, in mass of 1: 2: 2.5 (cement: fine aggregate: coarse aggregate) with consistency, performed by the procedure specified in ABNT NBR NM 67:2003 [16], set at $90+/-10 \mathrm{~mm}$.

\subsection{Physical and chemical characterization of the materials}

The characteristics of the materials used in the concrete are directly related to the performance and properties of the mixture. For the characterization of materials, tests were performed according the ABNT norms.

\subsubsection{Portland Cement}

The Portland cement which was used was CP II E 32. It was specified because it is a cement with a lower rate of additions, among the commercially ones available, and for not being a cement with high initial resistance. The specific mass used for the Portland cement was $\rho=3000 \mathrm{~kg} / \mathrm{m}^{3}$, determined according to the ABNT norms NBR NM 23:1998 [17], while the mechanical and chemical properties are listed in Table 1.

\subsubsection{Aggregates}

The fine aggregate used was extracted from the river sand that presented a unitary mass $\rho=1419 \mathrm{~kg} / \mathrm{m}^{3}$, determined according to recommendation by the ABNT NBR NM 45:2006 [18], and density of $\rho=2618 \mathrm{~kg} / \mathrm{m}^{3}$, determined according to ABNT NBR 9776:1987 [19]. The coarse aggregate consists of crushed basaltic rock, with unit mass $\rho=1197 \mathrm{~kg} / \mathrm{m}^{3}$, performed according to ABNT NBR NM 45:2006 [18]. The density was determined at $\rho$ $=2590 \mathrm{~kg} / \mathrm{m}^{3}$, by the method of hydrostatic balance.

The test for sieve analysis of aggregates was performed according to ABNT NBR NM 248:2003 [20], which foresees the determination of particle size distribution of coarse and fine aggregates for concrete. The results are shown in Table 2.

\subsubsection{Water}

Water coming from the public water supply was used for the execution of concrete.

\section{Table 3 - Water/cement ratio and consistency of molding}

\begin{tabular}{|cccc|}
\hline \multicolumn{2}{c}{ Moldings } & a/c ratio & Consistency $(\mathrm{mm})$ \\
\hline $1^{\mathrm{a}}$ & $25^{\circ} \mathrm{C}$ & 0,58 & 80 \\
$2^{\mathrm{a}}$ & $20^{\circ} \mathrm{C}$ & 0,56 & 90 \\
$3^{\mathrm{a}}$ & $15^{\circ} \mathrm{C}$ & 0,57 & 100 \\
$4^{\mathrm{a}}$ & $10^{\circ} \mathrm{C}$ & 0,56 & 100 \\
$5^{\mathrm{a}}$ & $5^{\circ} \mathrm{C}$ & 0,55 & 90 \\
$6^{\mathrm{a}}$ & $0^{\circ} \mathrm{C}$ & 0,57 & 100 \\
\hline
\end{tabular}

\subsection{Mixture of concrete and molding of the specimens}

At this stage, 62 cylindrical specimens were molded for trials to compression and 10 traction trials samples for a total of 72 samples metal molded in shapes with dimensions of $10 \mathrm{~cm}$ of diameter and $20 \mathrm{~cm}$ in height, two for each age, for six curing temperatures. The mixture was conducted in a concrete mixer with vertical shaft, with maximum capacity of 56 liters and rotational speed of 29 revolutions per minute (RPM). The time for adding all materials and homogenization of the mixture for all moldings was $18 \pm 2 \mathrm{~min}$. The order of the material in the mixer was the following:

a) Course aggregate;

b) $80 \%$ of water;

c) Cement

d) Fine Aggregates;

e) $20 \%$ of water;

After the stage of mixing the materials, it was measured the consistency of concrete through testing the concrete Abram's cone, according to ABNT NBR NM 67:1996 [16]. It was established the $\mathrm{a} / \mathrm{c}$ ratio, the curing time and the consistency of the concrete, only for evaluating the influence of the curing temperatures on the mechanical properties of materials. The time for conducting the test was $8 \pm 2$ minutes. The results of the slumps and a/c ratio are presented in Table 3. The concretes analyzed are similar, with all properties fixed, in order to analyze only the influence of the curing temperature in the final properties of the material.

Afterwards, the samples were molded in a period of $25 \pm 2$ minutes. Thus, the total time between the contact of the cement with water and the storage of specimens in the cure environment with controlled temperature at $51 \pm 6$ minutes.

3.3 Conditions of curing

The condition of cure of the samples was carried out in an environment of low controlled temperatures, simulating the behavior of the concrete when subjected to this incidence, as shows Table 4, and relative humidity of $50 \%$. The equipment used was a sealed box with digital temperature control, which allows setting the temperature without affecting the relative humidity of the air for a predetermined time, in the case study, for 7 days.

In this condition, by keeping the samples at various curing temperatures in the first seven days, the behavior of the first reactions which occur at early ages can be analyzed. 


\section{Table 4 - Weather conditions and temperature of the molding}

\begin{tabular}{|ccc|}
\hline Moldings & \multicolumn{3}{c|}{ Time and temperature of cure } \\
\hline $1^{\mathrm{a}}$ & 0 a 7 days & 8 a 91 days \\
$2^{\mathrm{a}}$ & $25^{\circ} \mathrm{C}$ & $20^{\circ} \mathrm{C}$ \\
$3^{\mathrm{a}}$ & $20^{\circ} \mathrm{C}$ & $20^{\circ} \mathrm{C}$ \\
$4^{\mathrm{a}}$ & $15^{\circ} \mathrm{C}$ & $20^{\circ} \mathrm{C}$ \\
$5^{\mathrm{a}}$ & $10^{\circ} \mathrm{C}$ & $20^{\circ} \mathrm{C}$ \\
$6^{\mathrm{a}}$ & $5^{\circ} \mathrm{C}$ & $20^{\circ} \mathrm{C}$ \\
\hline
\end{tabular}

\section{Presentation and Result Analysis}

After the rupture of the specimens in the mechanical tests, it was compared the results to reach conclusions regarding the subject.

\subsection{Trial of compression of the cylindrical specimens}

The results of the resistance to compression were divided into two stages, because it presents different behaviors. The first stage ranged from 1 to 7 days, while the second stage was conducted from 8 to 91 days.

The Table 5 shows the evolution of the resistance compression in the first 7 days, when the samples were conditioned to a controlled cure at low temperatures, ranging from $0^{\circ}$ to $25^{\circ} \mathrm{C}$ at $5^{\circ} \mathrm{C}$.

For better viewing, it was presented the results in Figure 1, relating the resistance compression in MPa, in the ' $y$ ' axis at the age of rupture of the samples of the trial in ' $x$ ' axis, in days.

In this first period of curing it can be observed a greater variation of resistance in the first day of measurement, which was $11.4 \mathrm{MPa}$ for a temperature of $25^{\circ} \mathrm{C}$ and at $1.2 \mathrm{MPa}$ for a temperature of $0{ }^{\circ} \mathrm{C}$. The higher curing temperatures presented superior outcomes of resistance

\begin{tabular}{|c|c|c|}
\hline \multicolumn{3}{|c|}{$\begin{array}{l}\text { Table } 5 \text { - Evolution of compressive } \\
\text { strength in healing controlled }\end{array}$} \\
\hline \multicolumn{3}{|c|}{ Compressive strength } \\
\hline${ }^{\circ} \mathrm{C}$ & $\begin{array}{l}1 \text { day } \\
\text { (MPa) }\end{array}$ & $\begin{array}{l}7 \text { days } \\
\text { (MPa) }\end{array}$ \\
\hline 25 & 11,4 & 21,5 \\
\hline 20 & 11 & 23,4 \\
\hline 15 & 8,3 & 24,4 \\
\hline 10 & 6,5 & 21,7 \\
\hline 5 & 3,5 & 18 \\
\hline 0 & 1,2 & 18,8 \\
\hline
\end{tabular}

\section{Figure 1 - Evolution of compressive strength in the first 7 days in controlled healing}

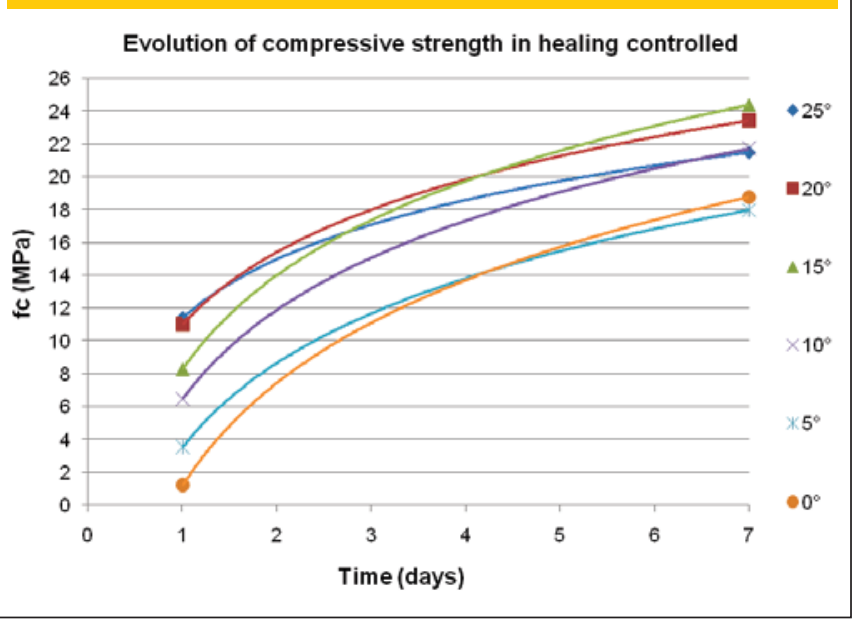

to compression and the resistance was gradually decreased to the lowest temperature with the worst performance, as might be expected.

On the seventh day this variation was $24.4 \mathrm{MPa}$ for a temperature of $15{ }^{\circ} \mathrm{C}$ and at $18 \mathrm{MPa}$ for a temperature of $5{ }^{\circ} \mathrm{C}$. The difference between the highest and lowest value decreased $37.25 \%$ compared to the first period. That is, in the 7 days of curing, the influence of initial curing temperatures have been lower, reaching even to overlap different curves. Although the resistance gain was more significant for cured concretes at lower temperatures, approaching the cured concrete resistance at $0{ }^{\circ} \mathrm{C}$ increased about $1,600 \%$ between the 1 st and 7 th day, compared to a gain of $88 \%$ of the cured at $25^{\circ} \mathrm{C}$.

Table 6 shows the evolution of resistance from 14 to 91 days of curing. It is also illustrated in Figure 2, the results in chart form, for better viewing.

In the second period of cure it is observed the approximation of the results from day 7 , the inversion in resistance values occurring

\begin{tabular}{|c|c|c|c|}
\hline \multicolumn{4}{|c|}{$\begin{array}{l}\text { Table } 6 \text { - Evolution of resistance to } \\
\text { compression in air-conditioned room }\left(20^{\circ} \mathrm{C}\right)\end{array}$} \\
\hline \multicolumn{4}{|c|}{ Compressive strength } \\
\hline${ }^{\circ} \mathrm{C}$ & $\begin{array}{l}14 \text { days } \\
\text { (MPa) }\end{array}$ & $\begin{array}{l}28 \text { days } \\
\text { (MPa) }\end{array}$ & $\begin{array}{l}91 \text { days } \\
\text { (MPa) }\end{array}$ \\
\hline 25 & 24,3 & 26,9 & 29,2 \\
\hline 20 & 27,5 & 31 & 31,4 \\
\hline 15 & 28,7 & 21,7 & 27,8 \\
\hline 10 & 27,3 & 31,8 & 28,7 \\
\hline 5 & 20,9 & 35,6 & 37,6 \\
\hline 0 & 30,3 & 38,6 & 38,8 \\
\hline
\end{tabular}




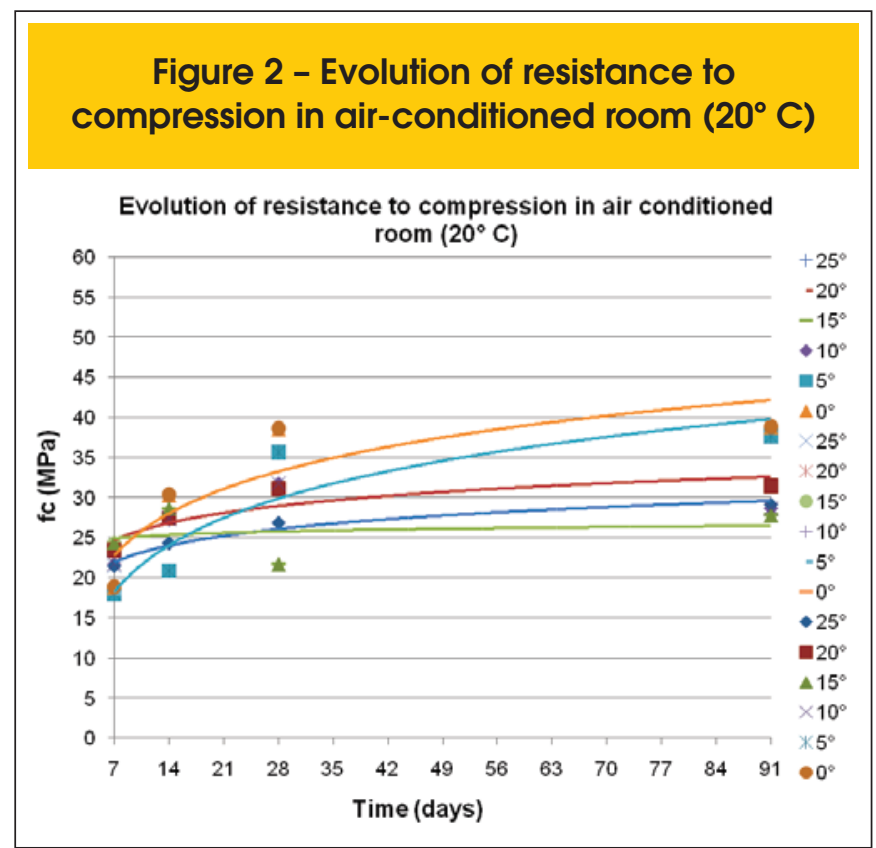

from day 14 , with the concrete cured at lower temperatures and showing better results than those cured at higher temperatures. At 28 days the ratio of resistance with the previous age followed the trend of higher growth for lower temperatures. The variation of resistance at this age was $21.7 \mathrm{MPa}$ for a temperature of $15^{\circ} \mathrm{C}, 38.6 \mathrm{MPa}$ for a temperature of $0{ }^{\circ} \mathrm{C}$, considering a $43 \%$ reduction in the range of $15{ }^{\circ} \mathrm{C}$, for the total range of $25^{\circ} \mathrm{C}$ the reduction was $30 \%$, similar to the results in the referenced bibliography. For the age of 91 days the ratio between the resistance of the concretes maintained the tendency, with the cured at zero and $5^{\circ} \mathrm{C}$ with higher rates of resistance to compression. It is presented in Table 7 with all values grouped. Figure 3 shows the behavior in graph form, where it was observed the highest resistance to compression for concretes cured under high temperatures at early ages, with the inversion occurring at 14 days, showing that the slow hydration is an advantage over time for the concrete structure.

Such behavior is evidenced in Figure 4, which correlates the compressive strength in $\mathrm{MPa}$, in the ' $\mathrm{y}$ ' axis, with the curing
Figure 3 - Evolution of compressive strength
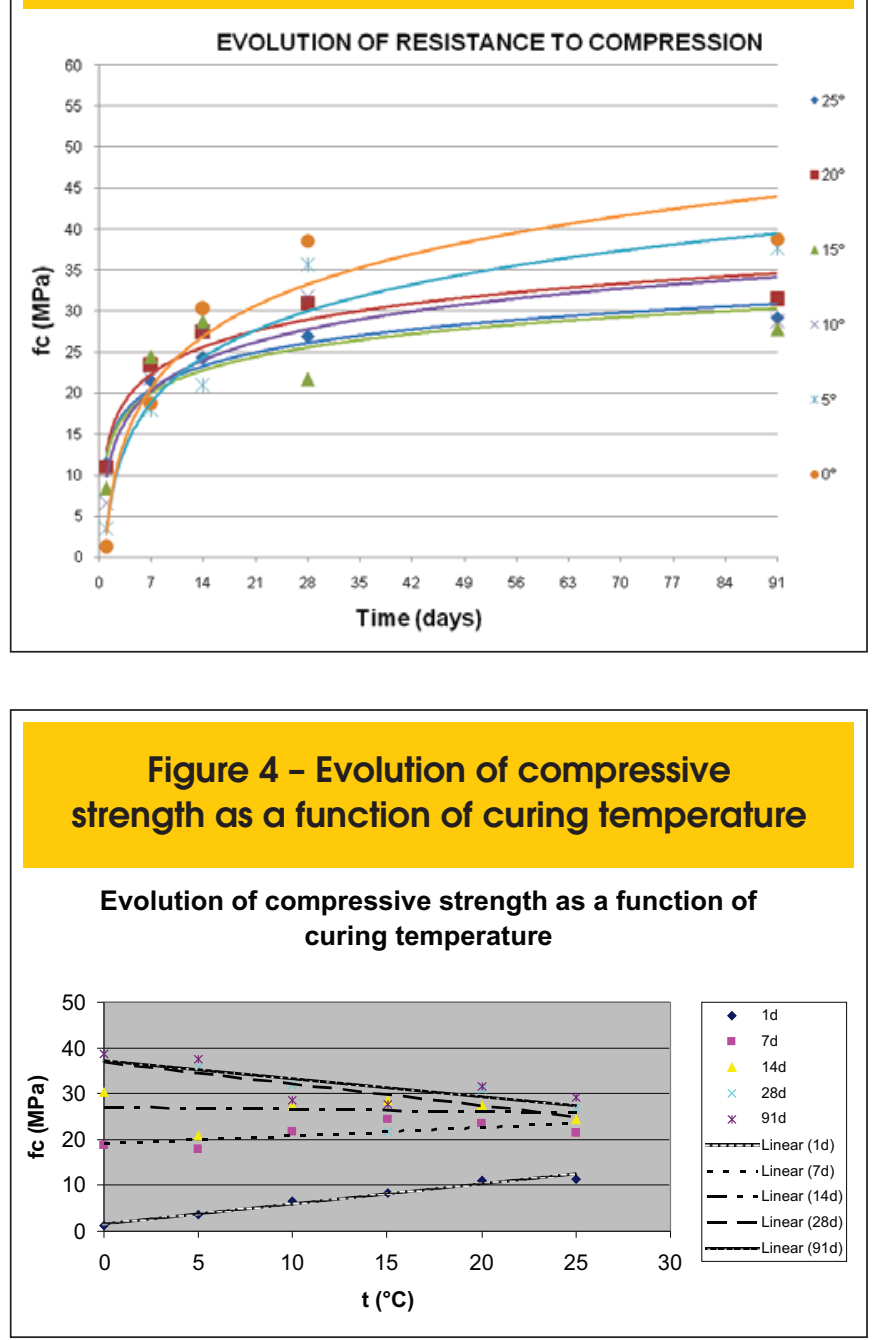

temperature, in ${ }^{\circ} \mathrm{C}$, in the axis ' $\mathrm{x}$ ' to the ages of the tests of the samples. It is observed the behavior of the outcomes at 1

Table 7 - Evolution of compressive strength at 91 days

\begin{tabular}{|c|c|c|c|c|c|}
\hline \multicolumn{6}{|c|}{ Resistência à compressão } \\
\hline${ }^{\circ} \mathrm{C}$ & $\begin{array}{l}1 \text { day } \\
\mathrm{MPa}\end{array}$ & $\begin{array}{l}7 \text { days } \\
\mathrm{MPa}\end{array}$ & $\begin{array}{c}14 \text { days } \\
\mathrm{MPa}\end{array}$ & $\begin{array}{c}28 \text { days } \\
\mathrm{MPa}\end{array}$ & $\begin{array}{l}91 \text { days } \\
\mathrm{MPa}\end{array}$ \\
\hline 25 & 11,4 & 21,5 & 24,3 & 26,9 & 29,2 \\
\hline 20 & 11 & 23,4 & 27,5 & 31 & 31,4 \\
\hline 15 & 8,3 & 24,4 & 28,7 & 21,7 & 27,8 \\
\hline 10 & 6,5 & 21,7 & 27,3 & 31,8 & 28,7 \\
\hline 5 & 3,5 & 18 & 20,9 & 35,6 & 37,6 \\
\hline 0 & 1,2 & 18,8 & 30,3 & 38,6 & 38,8 \\
\hline
\end{tabular}




\begin{tabular}{|c|c|}
\hline \multicolumn{2}{|c|}{$\begin{array}{l}\text { Table } 8 \text { - Behavioral equations relating the } \\
\text { compressive strength and curing temperature }\end{array}$} \\
\hline Property & Equation behavior \\
\hline 1 day & $f c=0,4303^{*} \dagger+1,6048$ \\
\hline 7 days & $f C=1,1851^{*} \dagger+18,986$ \\
\hline 14 days & $f C=-0,0503^{*} t+27,129$ \\
\hline 28 days & $f c=-0,4709^{*} \dagger+36,819$ \\
\hline 91 days & $f c=-0,3857^{*}++37,071$ \\
\hline
\end{tabular}

day is increasing, that is, the higher the cure temperature, the higher the compression resistance at this age. This trend is again observed at 7 days, but more smoothly. At 14 days the equation is almost linear, thus independent of the curing temperature on the compression resistance is similar. While at 28 to 91 days the behavior of the results is decreasing, that is, the concrete compression resistance is affected by the increase of the curing temperature.

For all ages there were determined behavioral equations, shown in Table 8. The described behavior can be analyzed through equations, for the first number, which multiplies the ' $t$ ' (cure temperature) is positive for increasing results at 1 and 7 days, close to zero at 14 days, showing the linearity and negative when the values decrease to 28 and 91 days. Yet, the isolated portion of the equation represents the value that the line intersects the axis ' $y$ ', that is, the compressive strength when cured at $0{ }^{\circ} \mathrm{C}$. This value is higher for curing temperatures that provided the greatest resistance to compression and lower for those who reached the lowest values, it means, higher for higher temperatures.

\subsection{Trial to determine the resistance to traction by diametrical compression of the cylindrical specimens}

The presentation of the resistance to traction results at 28 days of curing are shown in Table 9. Figure 5 illustrates the behavior of the

\begin{tabular}{|cc|}
\hline \multicolumn{2}{|c|}{ Table 9 - Tensile strength at 28 days } \\
\hline \multicolumn{3}{|c|}{ Traction resistance } \\
\hline Temperature $\left({ }^{\circ} \mathrm{C}\right)$ & 28 days $(\mathrm{MPa})$ \\
\hline 25 & 9,0 \\
20 & 10,5 \\
15 & 10,0 \\
10 & 10,8 \\
5 & 11,3 \\
0 & 13,2 \\
\hline
\end{tabular}

Figure 5 - Traction resistance at 28 days

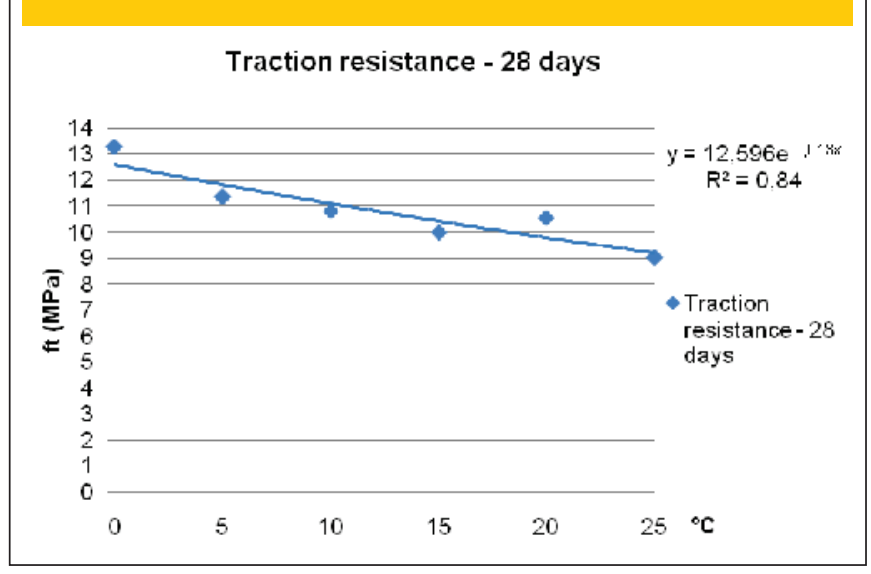

equation, relating the resistance to traction, in the ' $y$ ' axis, with the curing temperature in ${ }^{\circ} \mathrm{C}$, in the ' $\mathrm{x}$ ' axis.

It is observed that, again, the results at 28 days were higher than the cured concretes at lower temperatures, confirming the behavior seen for the resistance to compression. The resistance variation for age was $9.0 \mathrm{MPa}$ to $25^{\circ} \mathrm{C}, 13.2 \mathrm{MPa}$ for a temperature of 0 ${ }^{\circ} \mathrm{C}$, considering a $31 \%$ reduction in the range of $25^{\circ} \mathrm{C}$, approaching the results presented in referenced bibliography. And the correlation coefficient was 0.85 , considered to be acceptable for this type of trial.

\section{Conclusions}

After carrying out this study, it can be observed in the early ages, between 1 and 7 days, the resistance to compression of cured concrete at higher temperatures was higher compared to the resistance to lower curing temperatures, as was expected. At these ages the increase in resistance was due to the high degree of hydration of these parts, explained by the high value of the activation energy. It is noteworthy the curing temperatures of $20^{\circ} \mathrm{C}$ and $25^{\circ} \mathrm{C}$ for 1 day, which showed the highest values. However, on day 7 , when the activation energy does not exercise much influence in the parts, the resistance had increased closeness

From the day 14 there was an inversion in the samples of greatest resistance, that is, those who were initially cured at low temperatures achieved the best results, but with lower differences between them. These differences increased at 28 days, with the best performance to the parts initially cured at $0{ }^{\circ} \mathrm{C}$. Finally, it was proven that the more slowly it is the hydration of Portland cement, the better the formation of its crystalline structure, thus justifying superior performance for the parts cured in its early ages at low temperatures, that is, temperatures which slow down and / or slow the hydration process.

\section{References}

[01] HELENE, P. R. L.; LEVY S. M. "Estado da arte" do concreto como material de construção. São Paulo: Exacta. 2003. 8p. 
[02] SHOUKRY, S. N.; WILLIAM, G. W.; DOWNIE, B.; RIAD, M. Y.; Effect of moisture and temperature on the mechanical properties of concrete. USAL: Elsevier, 2010.

[03] ASSOCIAÇÃO BRASILEIRA DE NORMAS TÉCNICAS. NBR 6118. Projeto de estruturas de concreto. Procedimento. Rio de Janeiro: ABNT, 2007.

[04] MEHTA, P. K.; MONTEIRO, P. J. M. Concreto: microestrutura, propriedades e materiais. São Paulo: Ibracon, 2008. 674 p.

[05] ISAIA, G. C. Concreto: ensino, pesquisa e realizações. São Paulo: IBRACON, 2005. 1600p.

[06] ANKA ILC; GORAN TURK; FRANCI KAVCIC; GREGOR TRTNIK. New numerical procedure for the prediction of temperature development in early age concrete structures. USAL: Elsevier, 2009.

[07] NEVILLE, A M. Propriedades do concreto. Tradução Eng. Salvador E. Giammusso. São Paulo: Pini, 1997. $828 \mathrm{p}$.

[08] KIRCHHEIM, A. P.; SOUZA, R. B.; DAL MOLIN, D. C. C.; MONTEIRO, P. J. M. Álcalis incorporados ao aluminato tricálcico: efeitos na hidratação. Ambiente construído. 2010. 14p.

[09] TAYLOR H. F. W. La quimica de los cementos. Bilbao: Urmo, 1967. $512 \mathrm{p}$.

[10] ZHANG, J.; CUSSON, D.; MONTEIRO, P.; HARVEY, J.; New perspectives on maturity method and approach for high. USAL: Elsevier, 2008.

[11] PINTO BARBOSA, M.; BERTOLUCCI, F. S.; PINTO, R. C. A.; PERES, L. D. P. Avaliação da energia aparente de ativação do cimento CP-II E CP-V com adição de superplastificantes. Anais do VI Simpósio EPUSP sobre Estruturas de Concreto, 2006. 15 p.

[12] KIM, J. K.; HAN, S. H.; SONG, Y. C.; Effect of temperature and aging on the mechanical properties of concrete Part I. Experimental results. USAL: Elsevier, 2002.

[13] HUSEM, M.; GOZUTOK, S.; The effects of low temperature curing on the compressive strength of ordinary and high performance concrete. USAL: Elsevier, 2004.

[14] CÁNOVAS, M. F. Patologia e terapia do concreto armado. São Paulo: PINI, 1988. 522 p;

[15] DEMIREL, B.; KELESTEMUR, O.; Effect of elevated temperature on the mechanical properties of concrete produced with finely ground pumice and silica fume. USAL: Elsevier, 2010.

[16] ASSOCIAÇÃO BRASILEIRA DE NORMAS TÉCNICAS. NBR NM 67. Concreto - Determinação da consistência pelo abatimento do tronco de cone. Rio de Janeiro: ABNT, 1998.

[17] ASSOCIAÇÃO BRASILEIRA DE NORMAS TÉCNICAS. NBR NM 23. Cimento. Determinação da massa específica. Rio de Janeiro: ABNT, 1998.

[18] ASSOCIAÇÃO BRASILEIRA DE NORMAS TÉCNICAS. NBR NM 45. Determinação da Massa Unitária de Agregados. Rio de Janeiro: ABNT, 2006.

[19] ASSOCIAÇÃO BRASILEIRA DE NORMAS TÉCNICAS. NBR 9776. Determinação da Massa Específica de
Agregados Miúdos - Por meio do frasco de Chapman. Rio de Janeiro: ABNT, 1987.

[20] ASSOCIAÇÃO BRASILEIRA DE NORMAS TÉCNICAS. NBR NM 248. Agregados - Determinação da composição granulométrica. Rio de Janeiro: ABNT, 2003. 